\title{
Pengaruh Tingkat Pengetahuan Dan Sikap Terhadap Perilaku Penanganan Sanitasi Lingkungan Masyarakat Di Kota Palu
}

\author{
Miswan $^{1 *}$, Rusman Rasyid ${ }^{2}$ \\ ${ }^{1}$ Fakultas Matematika dan Ilmu Pengetahuan Alam, \\ Universitas Tadulako, Palu \\ Email: miswan.wangling@gmail.com \\ 2 Pendidikan Geografi, Fakultas Kegurauan dan Ilmu Pendidikan, \\ Universitas Khairun Ternate \\ Email: rusman rasyid68@unkhair.ac.id
}

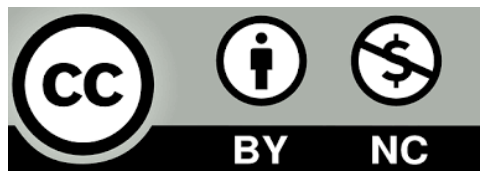

(C) 2020 - UEJ Program Studi Pendidikan Kependudukan dan Lingkungan Hidup Universitas Negeri Makassar. Ini adalah artikel dengan akses terbuka dibawah Licensi CC BY-NC-4.0(http:/creativecommons.org/licenses/by-nc/4.0)

\begin{abstract}
.
Sanitation as one of the aspects of development has an important function in supporting the level of people's welfare because it is related to health, lifestyle, residential environment conditions, aesthetics and comfort in everyday life. Sanitation is one of the most important factors in realizing services related to poverty alleviation and increased productivity. This study aims to determine the effect of knowledge and attitudes in handling environmental sanitation. The design of this study is based on the SEM model, assuming that all variables are considered to have direct or indirect influence. This type of research is a quantitative study through the survey research phase. In the survey, research was not carried out on all objects studied or population, but only took part of the population (sample) of the community, namely to describe the influence of knowledge and attitudes in handling environmental sanitation. The results of the study show that the knowledge environment variable has a direct or indirect influence on the variable behavior of the community in handling environmental sanitation. While the indirect influence of this variable is through the influence on attitudes in managing the environment.
\end{abstract}

Keywords: Knowledge; Attitude; Environmental Sanitation

\begin{abstract}
Abstrak.
Sanitasi sebagai salah satu aspek pembangunan memiliki fungsi penting dalam menunjang tingkat kesejahteraan masyarakat karena berkaitan dengan kesehatan, pola hidup, kondisi lingkungan permukiman, estetika serta kenyamanan dalam kehidupan sehari - hari. Sanitasi merupakan salah satu faktor terpenting dalam mewujudkan layanan yang terkait dengan pengentasan kemiskinan dan peningkatan produktivitas. Penelitian ini bertujuan Untuk mengetahui pengaruh pengetahuan dan sikap dalam penanganan sanitasi lingkungan. Desain penelitian ini berdasarkan model SEM, diasumsikan bahwa semua variabel dianggap mempunyai pengaruh secara langsung maupun tidak langsung. Jenis Penelitian ini merupakan penelitian kuantitatif melalui tahap penelitian survey. Dalam survei, penelitian tidak dilakukan terhadap seluruh objek yang diteliti atau populasi, tetapi hanya mengambil sebagian dari populasi (sampel) masyarakatya itu untuk menggambarkan pengaruh pengetahuan dan sikap dalam penanganan sanitasi lingkungan. Hasil penelitian menunjukkan bahwa variabel pengetahuan lingkungan memiliki pengaruh langsung maupun tidak langsung terhadap variabel perilaku masyarakat dalam penanganan sanitasi lingkungan, sedangkan
\end{abstract}


pengaruh tidak langsung variabel ini melalui pengaruh terhadap sikap dalam mengelola lingkungan.

Kata Kunci: Pengetahuan; Sikap; Sanitasi Lingkungan

\section{PENDAHULUAN}

Sanitasi sebagai salah satu aspek pembangunan memiliki fungsi penting dalam menunjang tingkat kesejahteraan masyarakat karena berkaitan dengan kesehatan, pola hidup, kondisi lingkungan permukiman, estetika serta kenyamanan dalam kehidupan sehari - hari. Sanitasi merupakan salah satu faktor terpenting dalam mewujudkan layanan yang terkait dengan pengentasan kemiskinan dan peningkatan produktivitas(Amos, 2008). Namun masih sering dijumpai bahwa aspek - aspek pembangunan sanitasi yang meliputi air limbah, persampahan dan drainase, termasuk penyediaan air bersih dan Prilaku Hidup Bersih dan Sehat (PHBS), masih berjalan sendiri - sendiri. Meski pun masuk dalam satu bidang pembangunan yaitu sanitasi tetapi masing - masing aspek tersebut ditangani secara terpisah sehingga banyak terjadi tumpang tindih kegiatan pembangunan bidang sanitasi oleh institusi yang berbeda-beda, disisi lain masih banyak ditemui aspek sanitasi yang belum tertangani oleh siapapun.(Khoiron \& Rokhmah, 2015)

Isu tentang permasalahan Sanitasi merupakan satu dari 17 Tujuan dari Sustainable Development Goal (SDGs), Satu dari 17 tujuan SDG menyangkut Sanitasi tersebut adalah Menjamin Ketersediaan serta Pengelolaan Air Bersih dan Sanitasi yang Berkelanjutan untuk Semua. Untuk mencapai tujuan SDGs tentang menjamin ketersediaan dan manajemen air dan sanitasi targetnya adalah penyediaan air bersih; mencapai akses sanitasi dan higienis untuk pembuangan tinja yang layak dan merata untuk semua orang; meningkatkan kualitas air dengan mengurangi polusi; melaksanakan penerapan manajemen air yang terintegrasi melindungi dan memulihkan ekosistem yang berhubungan dengan air; dan mendukung partisipasi komunitas lokal untuk meningkatkan manajemen air dan sanitasi. (Emil, 1991)

Penanganan sanitasi lingkungan oleh pemerintah sampai saat ini mesih menghadapi banyak kendala. Jumlah fasilitas yang ada tidak sebanding dengan pertumbuhan penduduk. Selain itu masyarakat dibanyak wilayah masih mempraktekkan perilaku hidup yang tidak sehat, seperti buang air besar disembarang tempat, mencuci di sungai yang airnya kotor, dan membuang sampah sembarangan.

Berdasarkan uraian tersebut diatas, maka perlu dilakukan kajian tentang .Pengaruh tingkat pengetahuan dan sikap terhadapprilakupenanganan sanitasi lingkungan.

\section{BAHAN DAN METODE}

Penelitian tentang pengaruh pengetahuan dan sikap terhadap prilaku penanganan sanitasi lingkungan. Jenis Penelitian ini merupakan penelitian kuantitatif melalui tahap penelitian survey. Sedangkan lokasi penelitian ini dilakukan di Palu. Waktu penelitian ini telah dilaksanakan pada tahun 2018. Populasi dalam penelitian ini yaitu sebanyak 22.130 dengan sampel sebanyak 198kk, yang dihitung berdasarkan rumus Slovin.Pengambilan sampel dilakukan secara Proposional Stratified Sampling. Adapun Teknik analisia data yang digunakan adalah dengan menggunakan teknik Structural Equation Model (SEM). Structural Equation Model adalah analisis statistik multivariat yang mampu menganalisis hubungan variabel secara kompleks. 


\section{HASIL PENELITIAN}

\section{a) Tingkat Pengetahuan Lingkungan}

Nilai skor total variabel pengetahuan lingkungan dari 23 item pertanyaan berkisar antara 23-46 dengan nilai standard deviasi, yaitu 2.49. Jika nilai ini dibagi dengan jumlah item pertanyaan, maka didapatkan rata-rata hasil sebesar, yaitu 42.5. Dengan nilai seperti ini maka dapat dikatakan bahwa rata-rata tingkat pengetahuan lingkungan masyarakat yang diteliti tergolong tinggi, dengan distribusi frekuensi seperti ditunjukkan dalam tabel berikut:

Tabel Distribusi Frekuensi Pengetahuan Lingkungan

\begin{tabular}{cclccc}
\hline No & Interval & Kategori & Frekuensi & Presentase & Ket \\
\hline 1 & $43-47$ & Sangat tinggi & 134 & 68 & \\
\hline 2 & $38-42$ & Tinggi & 53 & 27 \\
\hline 3 & $33-37$ & Sedang & 9 & 5 \\
\hline 4 & $28-32$ & Rendah & 2 & 1 \\
\hline 5 & $23-27$ & Sangat rendah & 0 & 0 \\
\hline & & 198 & 100 \\
\hline
\end{tabular}

Sumber : Data primer, 2019

Berdasarkantabel tersebutdistribusi frekuensi pengetahuan lingkungan, masyarakat dikategorikan tinggi, yaitu 134 orang atau 68\% dan selanjutnya berkategori tinggi, yaitu 53 orang atau $27 \%$, kategori sedang sebesar 5 orang atau $9 \%$ dan kategori rendah 2 orang atau $1 \%$.

\section{b) Sikap dalam Mengelola Lingkungan}

Nilai skor total variabel sikap dalam mengelola lingkungan berdasarkan tabulasi data hasil penelitian berkisar antara 24-120 dengan nilai standar deviasi, yaitu 10.5. Setelah dibagi dengan 198 (jumlah responden) didapatkan rata-rata sebesar, yaitu 98,2. Nilai ini menggambarkan bahwa sikap masyarakat dalam mengelola lingkungan tergolong tinggi. Dengan distribusi frekuensi seperti ditunjukkan dalam Tabel berikut:

Tabel Distribusi Frekuensi Sikap dalam Mengelola Lingkungan

\begin{tabular}{|c|c|c|c|c|c|}
\hline No & Interval & Kategori & Frekuensi & Presentase & Ket \\
\hline 1 & $104-122$ & Sangat tinggi & 61 & 31 & \\
\hline 2 & $83-103$ & Tinggi & 122 & 62 & \\
\hline 3 & $64-84$ & Sedang & 15 & 8 & \\
\hline 4 & $44-63$ & Rendah & 0 & 0 & \\
\hline 5 & $24-43$ & Sangat rendah & 0 & 0 & \\
\hline & & & 198 & 100 & \\
\hline
\end{tabular}

Sumber : Data primer, 2019

Berdasarkan Tabel tersebut distribusi frekuensi sikap dalam Mengelola Lingkungan diperoleh sebanyak 61 orang atau 31\% berada pada kategori sangat tinggi, 122 orang atau $62 \%$ berada pada kategori tinggi, dan sebanyak 15 orang atau $8 \%$ pada kategori sedang Artinya kesiapan bertindak dan bersikap masyarakat tergolong sedang.

\section{c) Perilaku Masyarakat dalam Penanganan Sanitasi Lingkungan}

Nilai skor total variabel perilaku masyarakat dalam penanganan sanitasi lingkungan yang dihitung dari 17 item pertanyaan dan 198 responden berkisar antara 17-85 dengan nilai standard deviasi, yaitu 9,09. Setelah nilai tersebut dibagi dengan jumlah item pertanyaan (17 item) maka didapatkan rata-rata sebesar 73,8. Nilai ini menunjukkan bahwa rata-rata 
masyarakat pada kelima kelurahan yang diteliti memiliki perilaku masyarakat dalam penanganan sanitasi lingkungan tergolong sangat tinggi, dengan distribusi frekuensi seperti ditunjukkan dalam tabel berikut:

Tabel Distribusi Frekuensi Perilaku dalam penanganan sanitasi lingkungan

\begin{tabular}{rclccc}
\hline \multicolumn{1}{l}{ No } & Interval & Kategori & Frekuensi & Presentase & Ket \\
\hline 1 & $73-86$ & Sangat tinggi & 116 & 59 & \\
\hline 2 & $59-72$ & Tinggi & 65 & 33 & \\
\hline 3 & $45-58$ & Sedang & 17 & 9 & \\
\hline 4 & $31-44$ & Rendah & 0 & 0 & \\
\hline 5 & $17-30$ & Sangat rendah & 0 & 0 & \\
\hline & Jumlah & & 198 & $100 \%$ &
\end{tabular}

Sumber : Data primer, 2019

Berdasarkan Tabel tersebut distribusi frekuensi perilaku masyarakat dalam penanganan sanitasi lingkungan sangat tinggi, yaitu 59\%. Kemudian disusul pada kategori tinggi, yaitu $33 \%$ dan kategori sedang berada pada 17\%. Hal ini menunjukkan bahwa Perilaku dalam penanganan sanitasi lingkungan sesuai yang diharapkan.

\section{PEMBAHASAN}

Sanitasi sebagai salah satu aspek pembangunan memiliki fungsi penting dalam menunjang tingkat kesejahteraan masyarakat karena berkaitan dengan kesehatan, pola hidup, kondisi lingkungan permukiman, estetika serta kenyamanan dalam kehidupan sehari - hari. Sanitasi merupakan salah satu faktor terpenting dalam mewujudkan layanan yang terkait dengan pengentasan kemiskinan dan peningkatan produktivitas. Namun masih sering dijumpai bahwa aspek - aspek pembangunan sanitasi yang meliputi air limbah, persampahan dan drainase, termasuk penyediaan air bersih dan Prilaku Hidup Bersih dan Sehat (PHBS), masih berjalan sendiri - sendiri.

Penanganan sanitasi lingkungan oleh pemerintah sampai saat ini mesih menghadapi banyak kendala. Jumlah fasilitas yang ada tidak sebanding dengan pertumbuhan penduduk. Selain itu masyarakat dibanyak wilayah masih mempraktekkan perilaku hidup yang tidak sehat, seperti buang air besar disembarang tempat, mencuci di sungai yang airnya kotor, dan membuang sampah sembarangan. Hasil penelitian berdasarkan analisis SEM, menunjukan bahwa Besarnya pengaruh pengetahuan lingkungan terhadap sikap dalam mengelola lingkungan sebesar 0,68 dengan nilai probabilitas $(\mathrm{P})$ 0,00001 dinyatakan bahwa Pengetahuan lingkungan berpengaruh terhadap sikap dalam mengelola lingkungan. Mengacu pada tanda koefisien maka disimpulkan bahwa pengaruh pengetahuan lingkungan terhadap sikap masyarakat dalam penangnan sanitasi lingkungan adalah positif dengan kecenderungan sikap masyarakat dalam penangnan sanitasi seiring dengan meningkatnya pengetahuan lingkungan.

Dari pengalaman dan penelitian terbukti bahwa perilaku yang di dasari oleh pengetahuan akan lebih langgeng daripada perilaku yang tidak didasari oleh pengetahuan (Notoatmodjo, 2010).

Pengetahuan atau kognitif juga merupakan domain yang sangat penting untuk terbentuknya tindakan seseorang (ovent behavior). Dari pengalaman dan penelitian, ternyata perilaku yang didasari oleh pengetahuan akan lebih langgeng daripada perilaku yang tidak didasari oleh pengetahuan. Pengetahuan sangat erat hubungannya dengan pendidikan, dimana diharapkan bahwa dengan pendidikan yang tinggi, maka orang tersebut akan semakin luas pula pengetahuannya (Djewarut, 2012). 
Sedangkan Pengetahuan lingkungan tidak berpengaruh terhadap perilaku masyarakat dalam penanganan sanitasi lingkungan. Dengan Besarnya pengaruh pengetahuan lingkungan terhadap perilaku masyarakat dalam penanganan sanitasi lingkungan sebesar 0,221 dengan nilai probabilitas $(\mathrm{P})$ 0,055.

\section{KESIMPULAN}

Hasil penelitian berdasarkan analisis SEM, menunjukan bahwa Besarnya pengaruh pengetahuan lingkungan terhadap sikap dalam mengelola lingkungan sebesar 0,68 dengan nilai probabilitas (P) 0,00001 dinyatakan bahwa Pengetahuan lingkungan berpengaruh terhadap sikap dalam mengelola lingkungan. Sedangkan Pengetahuan lingkungan tidak berpengaruh terhadap perilaku masyarakat dalam penanganan sanitasi lingkungan. Dengan Besarnya pengaruh pengetahuan lingkungan terhadap perilaku masyarakat dalam penanganan sanitasi lingkungan sebesar 0,221 dengan nilai probabilitas (P) 0,055 .

Hasil penelitian menyarankan agar dapat menjadi bahan tambahan informasi bagi praktisi kesehatan sebagai rujukan dalam melaksanakan penelitian selanjutnya serta sebagai bahan pertimbangan untuk mengambil kebijakan khususnya tetang hal-hal yang berhubungan sanitasi lingkungan.

\section{Referensi}

Amos Neolaka (2008). Kesadaran Lingkungan. Jakarta: PT Rineka Cipta

Djewarut H. 2012. Hubungan tingkat pengetahuan perawat tentang perawatan spiritual dengan pelaksanaan intervensi spiritual di RS Dadi Makassar. Jurnal Ilmiah Media Kesehatan; IV (1).

Emil Salim, 1991. Pembangunan Berwawasan Lingkungan, Jakarta: PT. Mediatama. Sarana

Khoiron dan Dewi Rokhmah. 2015. Perilaku Masyarakat Dalam Pengelolaan Sanitasi Lingkungan Pemukiman Di Perkebunan Kopi Kabupaten Jember. Buletin Penelitian Sistem Kesehatan - Vol. 18 No. 2 April 2015: 187-195.

Notoatmodjo, S , 2010. Ilmu Perilaku Kesehatan, Rineka Cipta, Jakarta. 